\title{
Determinants of Constructive Deviance: The Mediator Role of Psychological Ownership
}

\author{
Bora Yıldız ${ }^{1}$, Lütfihak Alpkan², Hamza Ateş ${ }^{3} \&$ Bülent Sezen ${ }^{1}$ \\ ${ }^{1}$ Faculty of Business Administration, Gebze Technical University, Gebze, Turkey \\ ${ }^{2}$ Faculty of Management, Istanbul Technical University, Istanbul, Turkey \\ ${ }^{3}$ Faculty of Political Sciences, Istanbul Medeniyet University, Istanbul, Turkey \\ Correspondence: Bora Y1ldı, Faculty of Business Administration, Gebze Technical University, Gebze, Kocaeli, \\ Turkey. Tel: 90-555-721-3425. E-mail: dr.borayildiz@gmail.com
}

Received: January 25, 2015

Accepted: February 10, 2015

Online Published: March 25, 2015

doi:10.5539/ibr.v8n4p107

URL: http://dx.doi.org/10.5539/ibr.v8n4p107

\begin{abstract}
Today's organizations are more flexible, creative, innovative and decentralized than past organizations. Constructive deviant workplace behaviors have a vital importance for organizations in terms of their positive effects. Although numerous researchers in the literature have tried to determine and clarify antecedents and consequences of constructive deviant behaviors, studies on both psychological ownership and constructive deviance are limited. In this respect, after a literature review on the concept of constructive workplace deviance, this paper provides a theoretical framework on some rarely studied predictors (i.e. psychological ownership, participative decision making, person-organization fit, idealism, justice perception), where psychological ownership is supposed to play a mediator role. Managerial and further research implications are provided.
\end{abstract}

Keywords: constructive deviance, idealism, justice perception, participative decision making, person-organization fit, psychological ownership

\section{Introduction}

Workplace deviance is one of the most important research topics affecting well-being of organization and its members, thereby also having considerable impact on its outcomes. In the literature, there are two types of workplace deviance behaviors; namely, constructive and destructive (Bennet \& Stamper, 2001). Destructive deviant behaviors have been defined as "voluntary behavior that violates significant organizational norms and in so doing threatens the well-being of an organization and its members or both" (Robinson \& Bennett, 1995; Bennett \& Robinson, 2000). On the other hand, constructive deviant behaviors defined as "intentionally behaviors, which break significant organizational norms and rules to improve and contribute to well being of organization, its members or both" (Galperin, 2002). It is clear that these behaviors are not only harmful (destructive) (Yildiz \& Alpkan, 2014) but also can be beneficial (constructive) for organizations. In the literature, past researches mainly investigated the dark side of these behaviors (Yıldız \& Alpkan, 2014; Örücü \& Yıldız, 2014; Yildız \& Yildiz, 2014). However, workplace deviance has also positive and constructive impact on organizations and its member or both. For instance, constructive deviant workplace literature shows that violating significant organizational norms, to well-being of an organization, provides an innovative atmosphere (Howell \& Higgins, 1990; Robbins \& Galperin, 2010; Vadera et al., 2013). In this respect, the positive side of these behaviors was evaluated in this study.

Besides the aforementioned explanations, researches clearly indicate that constructive deviant workplace behaviors are getting more and more important in today's organizations. The recent studies with related to causes and consequences of constructive deviant workplace behaviors reflect the rising research interest in these behaviors. These studies include many individual and organizational factors. However the predictors, used in those studies, might trigger off constructive deviance not directly but trough some positive attitudes. In other words, according to Blau's (1964) social exchange theory perceptions cause attitudes that cause behaviors. In light of this theory, employees' personal feelings, expectations, perceptions, characteristics etc. may develop some positive attitudes towards the work and organization, which then cause some positive behaviors.

In this study, we highlighted psychological ownership as a positive attitude (Van Dyne \& Pierce, 2004) that links 
some possible predictors to constructive deviant behaviors. Despite its importance, relations between these two positive concepts, both at the expense of the organizational milieu and norms, psychological ownership -a positive attitude, and constructive workplace deviance -a set of positive behaviors, are rarely studied until now. Thus, the present study has two main research questions: (a) what might be some less studied antecedents of constructive deviant workplace behaviors, and (b) is psychological ownership a missing link between the antecedents and behaviors? It develops a conceptual model that incorporates some possible causes and a theoretical mediator for constructive deviant workplace behaviors.

The paper proceeds in the following manner. It begins with a literature review on constructive deviant workplace behaviors and psychological ownership. Then the mediator role of psychological ownership is discussed in the relations of idealism, participative decision-making, person-organization fit (P-O fit), and justice perceptions to constructive deviant behaviors. Lastly, conclusions and implications are forwarded.

\section{Constructive Deviant Workplace Behaviors and Psychological Ownership}

The concepts of constructive deviance and psychological ownership have gained popularity in recent organizational behavior studies. There are many different types of constructive deviance definitions according to different studies in the literature. For instance, constructive or positive workplace deviant behaviors are defined by Galperin (2002) as intentionally behaviors, which break significant organizational norms and rules to improve and contribute to well-being of organization or its members or both. In Spreitzer and Sonenshein's (2003) study this concept is defined as "intentional behaviors that depart from the norms of a referent group in honorable ways". Additionally, Warren (2003) defined it as "behavior that deviates from the reference group norms but conforms to hypernorms". To reach a more comprehensive definition, Vadera and colleagues (2013) combined these definitions as "behaviors that deviate from the norms of the reference group such that they benefit the reference group and conform to hypernorms". In line with this definition, it can be said that the concept of constructive deviance has three main characteristics; "(a) deviate from reference group norms, (b) benefit the reference group and (c) conform to hypernorms" (Vadera et al., 2013). Although these behaviors are out of the formal job definition, performing these behaviors assists to achieve organizational goals and gets benefit to the organization (Galperin \& Burke, 2006; Robbins \& Galperin, 2010). According to Galperin's (2012) study employees who break the organizational norms to organization's well-being are source of the innovation and pioneer actors of organizational change. Because of the innovation's increasing affect on competitive advantage, constructive deviance is a pivotal factor for organizations (Howell et al., 2005; Howell \& Higgins, 1990). Galperin and Burke (2006) categorized this construct into three dimensions; interpersonal constructive deviance, challenging organizational constructive deviance and innovative organizational constructive deviance. According to their definition interpersonal constructive deviance refers to such behaviors as; disobeying the others or reporting wrongdoing to co-workers to positive organizational change. Challenging organizational constructive deviance refers to such behaviors as; breaking organization's significant norms and rules to wellbeing of it. Lastly, innovative organizational constructive deviance refers to such behaviors as; searching for innovative methods to routine daily tasks and generating creative solutions to overcome problems.

Brief and Motowidlo (1986) stated that "acts such as helping, sharing, donating, cooperating, and volunteering are forms of the pro-social behavior". Like the other pro-social behaviors (i.e. organizational citizenship behavior, corporate social responsibility, employee voice, whistleblowing and creativity/innovation) constructive deviant behaviors are also pro-social behaviors (Spreitzer \& Sonenshein, 2004; Galperin, 2012). Although these constructs are located in the same category, constructive deviance differs from these constructs with some important aspects. For instance, although OCB and constructive deviance are similar in terms of their nature, which goes beyond the existing role expectations, OCB has a passive nature. In other words, OCB requires obeying to the organizational and managerial norms and rules. However, constructive deviance requires employee's proactive action to norm violation. Given the Crant's (2000) definition, proactive behaviors are defined as "taking initiative in improving current circumstances or creating new ones; it involves challenging the status quo rather than passively adapting to present conditions". According to this definition, we can say that employees engaging constructive deviance are more prone to risk-taking than the others (Galperin, 2012).

Although constructive deviance is an important factor in terms of facilitating innovation and organizational change, in comparison with the destructive deviant workplace behaviors, the studies, defining the antecedents of constructive deviance, are interestingly limited and require more theoretical and empirical approach to clarify its nature (Spreitzer \& Sonenshein, 2004; Robbins \& Galperin, 2010; Vadera et al., 2013). The antecedents of constructive deviant behaviors such as; psychological ownership (Chung \& Moon, 2011; Vandewalle et al., 1995), personality traits (Big Five) (Bodankin \& Tziner, 2009), cultural factors (Galperin, 2002) and leader-member-exchange (Tziner et al., 2010) have been widely studied in last decade. However, in Vadera and 
colleagues' (2013) study, they summed these factors into three mechanisms; intrinsic motivation, felt obligation and psychological empowerment. In this respect, intrinsic motivation refers to "the inherent tendency to seek out novelty and challenges, to extend and exercise one's capacities, to explore, and to learn" (Ryan \& Deci, 2000). According to Ateş et al. (2012) intrinsic motivation is an important factor affecting employee's satisfaction and self-motivation. Felt obligation is defined within Blau's (1964) social exchange theory. According to this theory, if people perceive their organizations positively, they may feel obligated to behave positively to contribute its well-being. Lastly, psychological empowerment refer to "a myriad of variables that work to fortify or strengthen the individual in some way, allowing her or him the capacity to engage in constructive deviance" (Vadera et al., 2013). Based on these studies, it is easy to say that there are some person and organization-related variables that relate to the constructive deviance and employees engage these behaviors via three mechanisms.

Psychological ownership, which can be accepted as a common result of work and organization-related positive factors, is one of rarely studied drivers of positive behaviors (e.g. Chung \& Moon, 2011; Avey et al., 2009; Vandewalle et al., 1995; Avey et al., 2012; Buchko, 1993; O'driscoll et al., 2006). Pierce and colleagues (2003) defined psychological ownership as "that state where an individual feels as though the target of ownership or a piece of that target is "theirs' (i.e., it is MINE!)". Pierce and colleagues (2001) also state that "feeling of possession and being tided an object psychologically" are root of the psychological ownership construct. Pierce and colleagues $(2001,2003)$ also state that psychological ownership is "an attitude with affective and cognitive elements". Therefore, given the people's satisfactions as a result of the possessiveness of target object, it can be said that satisfied people in organizations may engage in positive or constructive deviant behaviors. Psychological ownership as an attitudinal positive variable has been rarely related to deviant behaviors in the past literature. Although psychological ownership has a positive nature like organizational commitment, organizational citizenship behaviour, employee voice, job satisfaction, organizational effectiveness etc. (e.g. Avey et al., 2009, 2012; Buchko, 1993; Wagner et al., 2003), there is a paucity of research on this subject (Pierce \& Morgan, 1991). From this aspect, organizations should look psychological ownership as a must to its well-being.

Although psychological ownership, as a positive construct, conceptually differs from other related constructs, there is some confusion about it. To clarify this confusion, Pierce and colleagues (2001) stated that because of its possession and motivational bases, it is distinct from other constructs. Van Dyne and Pierce (2004) also clarified this confusion with a few examples. For instance, "Psychological ownership asks, "How much do I feel this organization (workplace) is mine?" Organizational commitment asks, "Why should I maintain my membership in this organization?" Organizational identification asks, "Who I am", Internalization ask "What do I believe?" Psychological empowerment asks, “ Do I feel capable and intrinsically motivated in my work role?" Job involvement asks "How important is the job and job performance to my self image?" (Van Dyne \& Pierce, 2004).

In social sciences many studies are explained in light of the Blau's (1964) social exchange theory (Suárez-Mendoza \& Zoghbi-Manrique-de-Lara, 2008). In this respect, because of this theory's interactional nature we can say that people have some positive and negative perceptions and these perceptions link some positive behaviors through some positive attitudes (Greenberg \& Scott, 1996; Konovsky \& Pugh, 1994). According to this theory, psychological ownership as a positive attitude might cause constructive deviance.

After the aforementioned explanations, we can say that the concept of psychological ownership has been widely studied in recent literature (Liu et al., 2012; Mayhew et al., 2007; Özler et al., 2008; Pierce et al., 2003, 2004; Sieger et al., 2011, 2013). However, its relation to constructive deviant behaviors is rarely studied (Chung \& Moon, 2011). Therefore, in the present study, we propose that using some new predictors with the mediating effect of psychological ownership can advance our understanding of constructive deviance construct. To achieve this, a conceptual model (see Figure 3) was developed.

\section{Mediator Roles of Psychological Ownership}

Studying and understanding constructive deviant workplace behaviors is an important research area because of its positive effects (Galperin, 2002; Howell \& Higgins, 1990; Robbins \& Galperin, 2010; Vadera et al., 2013). In literature, the studies trying to define predictors of constructive deviance are limited. Accordingly, the research interest, which is necessary to close this gap, is also limited. From this aspect, the main difference of the present study from the past researches is the mediator role of psychological ownership in the proposed model. Past researches indicate that psychological ownership is an attitude that has some positive effects on organizations (i.e. job satisfaction, performance, extra-role behavior, commitment, and reduced negative behaviors) (Pierce et al., 1992; Liu et al., 2012; Pierce et al., 2004; Avey et al., 2009; Sieger et al., 2013). Of course, psychological ownership has already been studied as mediator in past researches (see Table 1). However, 
in this study, predictor variables do not predict other positive behaviors but they are used as a predictor for constructive deviance. Additionally, these relations are not considered to be directly but they are considered to be through some positive attitudes in the proposed model. In other words, we propose that positive employee feelings may lead to positive behaviors through the positive attitudes, i.e. psychological ownership in this study.

Table 1. The mediator roles of psychological ownership

\begin{tabular}{|c|c|c|c|}
\hline Study & Independent Variables & Mediator Variable & Dependent Variables \\
\hline \multirow{2}{*}{ Wagner et al., 2003} & - Participation in employee ownership initiative & & - Employee attitudes toward the organization \\
\hline & - Climate of self determination & & - Financial Performance \\
\hline \multirow{2}{*}{ O'Driscoll et al., 2006} & - Autonomy & & - Organizational citizenship behavior \\
\hline & & Psychological & - Organizational commitment \\
\hline \multirow{2}{*}{ Mayhew et al., 2007} & - Work environment structure & Ownership & - Job satisfaction \\
\hline & & & - Organizational commitment \\
\hline \multirow{2}{*}{ Sieger et al., 2011} & - Distributive Justice & & - Affective commitment \\
\hline & - Procedural Justice & & - Job Satisfaction \\
\hline \multirow{3}{*}{ Liu et al., 2012} & - Self-managing team climate & & - Organizational based self esteem \\
\hline & - Participative decision-making & & - Affective commitment \\
\hline & & & - Organizational citizenship behavior \\
\hline Avey et al., 2012 & - Ethical leadership & & - Job satisfaction \\
\hline
\end{tabular}

\subsection{Mediator Role of Psychological Ownership in the Relation of Idealism to Constructive Deviant Workplace Behaviors}

The concept of ethics and ethics related constructs have been widely studied in recent literature (Arslan et al., 2013; Elçi \& Alpkan, 2009; Henle et al., 2005; Elçi et al., 2012). Most of these studies have mainly emphasized that ethics can be an important factor, which is a guide for actions and to evaluating the morally questionable activities. For instance, in Elçi and Alpkan's (2006) study, they found that ethical climate has a positive impact on the organizational citizenship behavior. In another study, a positive relationship was found between ethical climate and organizational performance (Elçi et al., 2004). On the other hand, many researches on constructive deviance have been studied with related to some personality traits, perceptions, attitudes and behaviors (Chung \& Moon, 2011; Vandewalle et al., 1995; Bodankin \& Tziner, 2009; Galperin, 2012; Tziner et al., 2010). Despite the numerous studies, there are paucity of research investigating the relationship between ethical ideology (idealism and relativism) and workplace deviance (Henle et al., 2005; Hastings \& Finegan, 2011). Of course, there are studies investigating the relationship among ethical ideology, personality, moral identity, perceived moral intensity and moral behaviors (McFerran et al., 2009; Nye \& Forsyth, 1984; Singhapakdi et al., 1999). However, there are very few studies investigating the direct relationship between ethical ideology and constructive deviance.

In Forsyth (1980), ethical ideology is categorized into two sub-dimensions; idealism and relativism. According to his definition relativism is defined as "the individual rejects universal moral rules in favor of relativism". In line with this definition it is clear that people who has a relativist characteristics do not fit the universal moral rules or moralization towards to these rules. In other words, relativists' actions depend upon the nature of situation instead of universal moral rules (Forsyth, 1992). Relativists believe that their moral reasoning depend on the situation. According to relativists, sometimes harm to others can be seen necessary. More over, relativists do not believe in the universal moral rules when judging what is wrong or right. The right depends on their personal value in that situation (Forsyth, 1992). The low-level relativists believe that there is always one right action, which is related to the universal moral rules but regardless of the context (Hastings \& Finegan, 2011). On the other hand people who have high-level idealistic characteristics, as opposite to relativism, presume that "desirable consequences can, with the right action, always be obtained". This definition shows that idealist people follow universal moral rules more than the relativists. According to idealists, harming others is wrong (Singhapakdi et al., 1999). They believe that wellbeing of others is more important than the other gains (Forsyth, 1992; Henle et al., 2005). However, low-level of it is not concern for the possible consequences to others. Forsyth (1980) classified these definitions in a $2 \times 2$ table; idealistic or non-idealistic and believe moral rules are 
universal or relative. However, to better understand this classification we showed this classification in a quadrant instead of $2 \times 2$ table (see Figure 1).

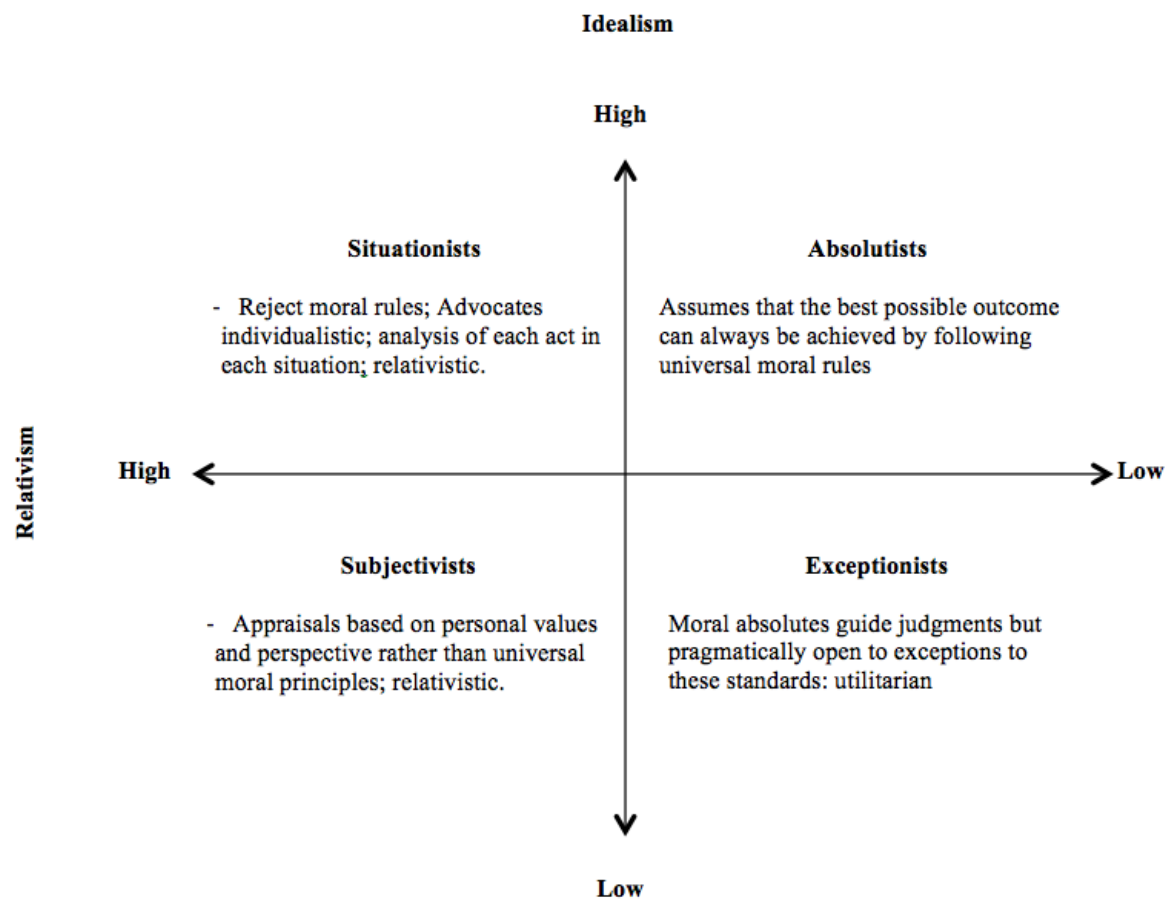

Figure 1. Taxonomy of ethical ideologies (Forsyth, 1980)

According to Figure 1, it can be said that Absolutist, who have high-level idealism and low-level relativism is the most idealistic character in this typology. Schlenker and Forsyht (1977) stated that "Exceptionists are more focus on the positive aspects". On the other hand, the common side of high-level relativism (i.e. Situationists, Subjectivists) is personal values that are more important than the universal moral rules.

Past researches indicate that ethical ideology is one of the significant predictors of workplace deviance (Henle et al., 2005; Hastings \& Finegan, 2011). Because of its ethically questionable nature, workplace deviance differs from person to person as a function of their ethical ideology (Henle et al., 2005). In their study, Hastings and Finegan (2011) state that employees with high-level idealism work for well-being of others and benefit them. Although the relationship between ethical ideology and destructive deviant workplace behaviors was investigated in past researches (Henle et al., 2005; Hastings \& Finegan, 2011), we did not find any study that investigates the relationship between constructive deviance and ethical ideology (idealism) in the literature. In aforementioned studies, the positive relationship between destructive deviance and relativism, and the negative relationship between idealism and destructive deviance were hypothesized. Although McHoskey (1996) suggested that idealists have fewer propensities to rule breaking, it may be valid for universal norms or rules but organizational norms or rules. It is also possible that idealist may break the rules to well being of the others trough some positive attitudes (i.e. psychological ownership). In this respect, because of its positive nature, it can be proposed that there may be a positive relationship between high-level idealism and constructive deviant workplace behaviors. Therefore, we propose that an employee who pursues idealist orientations may develop feeling of possession, which is core of the psychological ownership, towards to organization and then develop constructive deviant workplace behaviors.

Proposition 1: Psychological ownership mediates the positive relationship between idealism and constructive deviant workplace behaviors.

3.2 Mediator Role of Psychological Ownership in the Relation of Participative Decision Making to Constructive Deviant Workplace Behaviors

Quality, flexibility, and innovativeness are seen as critical concerns for organizational performance (e.g., Alpkan et al., 2003; Ergun et al., 2004) where employee participation is a must. Participative decision-making is defined 
by Aiken and Hage (1966) as "the degree to which staff members participate in setting the goals and policies of the entire organization". This concept is also defined by Pierce and colleagues (2004) as distribution of authority among employee in decision-making process. In Nassehi's (2005) study, he used "decision machine" metaphor to emphasize the importance of decision-making process in organizations. For instance, Eren et al. (2000) found that in most companies middle managers were consulted in the strategic planning process. Although poor level of it has undesirable effects on organizations such as; alienation, low-level performance (Aiken \& Hage, 1966; Allen \& LaFollette, 1977; Black \& Gregersen, 1997), high-level participation decision-making is also related to the some positive effects on organizations (i.e. organizational citizenship behavior, job satisfaction, organizational commitment, organization-based self-esteem) (Porter et al., 1996; Black \& Gregersen, 1997; Wagner et al., 2003; Bulut and Alpkan, 2006; Gilbert et al., 2010; Liu et al., 2012; Sieger et al., 2011). Additionally, there are also studies indicating the positive effects of it on employees (i.e. psychological ownership) (Chi \& Han, 2008). In their study, Chi and Han (2008) stated that employee's participation decision making is one of the significant predictors of psychological ownership. In Liu and colleagues' (2012) study, they found a positive relationship between participative decision-making and psychological ownership. Additionally, Wagner and colleagues (2003) found a positive relationship between psychological ownership and financial performance. Of course, in many studies positive outcomes of psychological ownership such as helping and extra-role behaviors, organizational commitment and job satisfaction were investigated. (Mayhew et al., 2007; Pierce et al., 2004; Avey et al., 2009; Sieger et al., 2013). However, there are limited researches focusing on the relationship between psychological ownership and constructive deviance (Chung \& Moon, 2011). In their study, Chung and Moon (2011) found a positive and significant relationship between interpersonal constructive deviance and psychological ownership. In light of these studies, it can be said that these constructs are widely studied in the past researches. However, to better understand these relations, a comprehensive model, which includes these three constructs (i.e. participative decision making, psychological ownership, and constructive deviance) is lacking in literature. Given the Blau's (1964) social exchange theory, if employees feel themselves as a part of their organizations and take part in decision-making process, they might develop some positive attitude and behaviors. Because of the participative decision-making as an antecedent of psychological ownership (Chi \& Han, 2008) and psychological ownership as an antecedent of constructive deviance (Chung \& Moon, 2011) we can propose that high-level participative decision-making might be a source of constructive deviance and psychological ownership may mediate this relationship. In other words, if employees feel themselves as a part of the decision making process in their organizations, they may develop a feeling of possession, which is psychologically, towards to organization and then exhibit constructive deviant workplace behaviors.

Proposition 2: Psychological ownership mediates the positive relationship between participative decision-making and constructive deviant workplace behaviors.

\subsection{Mediator Role of Psychological Ownership in the Relation of Justice Perception to Constructive Deviant Workplace Behavior}

The concept of organizational justice is based on Adam's $(1963,1965)$ equity theory. According to this theory, employees who has perception of inequity or injustice with related to the their organizations develop some cognitive and behavioral attitudes as a response to their organizations (Fox et al., 2001). This concept is related to the "employee's perception of fairness and just treatment on the job" (Fox et al., 2001). Although early stage of this concept mainly refers to distributive justice (e.g., Khan et al., 2013; Byrne \& Cropanzano, 2001; Greenberg, 1990b), there are also procedural and interactional justices. In line with this classification, it can be said that the concept of justice categorized into three sub-dimensions (Ambrose et al., 2002). Respectively, distributive justice refers to the perceived fairness of one's received outcomes such as pay (Skarlicki \& Folger, 1997; Folger \& Cropanzano, 1998), procedural justice refers to fairness of the procedures that are used to determine one's outcomes and decisions are made (Ambrose et al., 2002; Leventhal et al., 1980; Konovsky, 2000) and lastly interactional justice refers to "the quality of the interpersonal interaction between individuals" (Cropanzano et al., 2002). According to Henle (2005), this construct addresses the perception of fairness in the workplace and plays a critical role in explanation of the workplace deviance's situational based explanation. In this respect, justice is an important factor for organizations. In Trevino and Brown's (2005) study, they address that if employees perceive some unacceptable behaviors acted by other employees, they expect these behaviors will be punished. Conversely, if these acts are not punished, employees may feel disappointment and accordingly develop some negative behaviors (i.e. destructive deviance; sabotage, theft, stress, cyberloafing) (e.g., Yildiz et al., 2014; Syaebani \& Sobri, 2011; Ambrose et al., 2002; Jones \& Skarlicki, 2005; Greenberg, 1990; Judge \& Colquitt, 2004; Greenberg, 2004; Krings \& Facchin, 2009). 
In literature, fairness has a vital importance from the social exchange perspective (Konovsky \& Pugh, 1994; Vadera et al., 2013). To illustrate, in Appelbaum et al.'s (2007) study, they stated that employees compare their input-output ratio to others' ratios. As a result of this comparison, if employees perceive their ratios as similar to others, they may feel equity. Conversely, if they do not perceive fairness or equity with related to their ratios, they may feel inequity. Therefore, Henle (2005) states that employees, who experienced inequity, compensate this negative feeling as acting deviantlly. Additionally, Greenberg and Alge (1998) also emphasized that organizational justice is an up coming predictor of workplace deviance. From this point of view, if employees' perception of fairness is enough to their satisfaction they might have some positive attitudes and accordingly exhibit some positive behaviors. Although past studies indicate that poor level of organizational justice, in other words injustice, is associated with the negative outcomes, high-level of justice is also associated with some positive outcomes such as job satisfaction, organizational commitment, organizational citizenship behavior, positive work outcomes and constructive deviance etc. (e.g., Moorman, 1991; McFarlin \& Sweeney, 1992; Moorman et al., 1993; Ang et al., 2003; Appelbaum et al., 2007; Galperin, 2002; Vadera et al., 2013; Çakar et al., 2004). In this respect, it can be said that people having high-level of justice perception against to their organizations may exhibit constructive deviant behaviors.

Psychological ownership as an important positive attitude may play such a linking role between the employees' perception of justice and constructive deviant behaviors. As aforementioned, psychological ownership is associated with the constructive deviance (Chung \& Moon, 2011; Vandewalle et al., 1995) and it was used as mediator between some perceptions and positive behaviors (see Table 1). From these studies it can be understood that psychological ownership serves as a bridge between positive perceptions and behaviors. On the other hand, there are also studies investigating the relationship between organizational justice and psychological ownership (Chi \& Han, 2008). In their study, Chi and Han (2008) proposed that organizational justice (procedural and distributive) might play a mediator role in the relationship between formal ownership (profit sharing plans, participation decision-making and access to business information) and psychological ownership. However, in this study, the mediator role of psychological ownership was used between perceived organizational justice and constructive deviance. In the proposed model we suggest that if people perceive their organizational milieu as fair or equitable they may develop some positive attitudes (i.e. psychological ownership) and, in turn, exhibit some positive behaviors (i.e. constructive deviant behaviors). Therefore, in the proposed model, the perception of justice could work through the mechanism of psychological ownership.

Proposition 3: Psychological ownership mediates the positive relationship between justice perception and constructive deviant workplace behaviors.

\subsection{Mediator Role of Psychological Ownership in the Relation of Person-Organization Fit to Constructive Deviant Workplace Behaviors}

Generally, the principle of right person to right organization is a pivotal factor for business life. Organizations spend excessive effort (i.e. time, money, manpower) to do this. In this respect, Person-Organization fit (P-O fit) is critical for organizations. In the literature, there are many different definitions of it according to different studies. Kristof-Brown and colleagues' (2005) definition is one of them, which is "the compatibility between people and entire organization". Although this definition is broadly accepted in the literature, there is some confusion about it (Judge \& Ferris, 1992). Therefore, the following explanations are required to clarify these confusions. The first of these, distinction is between complementary fit and supplementary fit (Kristof, 1996). These two types of fit are defined by Muchinsky and Monahan (1987). They defined complementary fit as "it occurs when a person's characteristics make whole the environment or add to it what is missing". On the other hand, supplementary fit is defined as when a person "supplements, embellishes, or possesses characteristics which are similar to other individual in an environment". The second distinction is between needs-supplies and demand-abilities perspectives. From the needs-supplies perspective P-O fit occurs, when employee's expectations are satisfied by organization. On the other hand, from the demand-abilities perspective P-O fit occurs, when the employees has some skills to satisfy organizational requirements (Caplan, 1987). These two distinctions was integrated into one definition by Kirstof (1996). According to Kristof (1996), P-O fit defined as "the compatibility between people and organizations that occurs when: (a) at least one entity provides what the other needs, or (b) they share similar fundamental characteristics, or (c) both".

In the literature, many studies indicate that high-level of $\mathrm{P}-\mathrm{O}$ fit is associated with the some positive outcomes (i.e. job satisfaction, organizational performance, organizational commitment, and organizational citizenship behavior) (e.g. Elçi et al., 2008; Liu et al., 2010; O'Reilly et al., 1991; Bretz \& Judge, 1994; Suárez-Mendoza \& Zoghbi-Manrique-de-Lara, 2008). However, there are also studies, which relate to the undesirable effects of poor level of P-O fit such as; turnover intention, alienation, dissatisfaction, and counter productive workplace 
behaviors (e.g. Liu et al., 2010; Sharkavi et al., 2013, Jawad et al., 2013; Suárez-Mendoza \& Zoghbi-Manrique-de-Lara, 2008). These studies show that high-level of P-O fit is a desirable factor for organizations. Cable and Judge (1996) state that employee's perception of P-O fit is strongly associated with the employees' attitudes. Given the Balu's (1964) social exchange explanation, there are interactions among perceptions, attitudes and behaviours. In this respect, although we did not find any study that investigates the direct relationship between P-O fit and constructive deviance, according to this theory P-O fit can be a predictor of constructive deviance.

As aforementioned, psychological ownership, as a positive attitude, is associated with the constructive deviance (Chung \& Moon, 2011; Vandewalle et al., 1995). In Van Dyene and colleagues' (1994) study, they investigated the relationship between some predictors (i.e. positive job attitudes, cynicism, workplace values, motivating job characteristics, tenure, job level) and organizational citizenship behavior (OCB). Also, in their study, they suggested that the relationship is not directly but trough some possible mediators (Netemeyer et al., 1997; Podsakoff et al., 1990). Given the OCB is a pro-social behavior (Spreitzer \& Sonenshein, 2004; Galperin, 2012), constructive deviance, which is to focus on helping others, is also prosocial behavior. In other words, the relationship between $\mathrm{P}-\mathrm{O}$ fit and constructive deviance may not be directly but through some possible attitudes (i.e. psychological ownership). According to these studies, we propose that an employee, who feels that there is a good fit between his characteristics and those of the organization he serves, may develop feeling of possession, which is psychologically, and then engages in constructive deviant behaviors.

Proposition 4: Psychological ownership mediates the positive relationship between person-organization fit (P-O fit) and constructive deviant workplace behaviors.

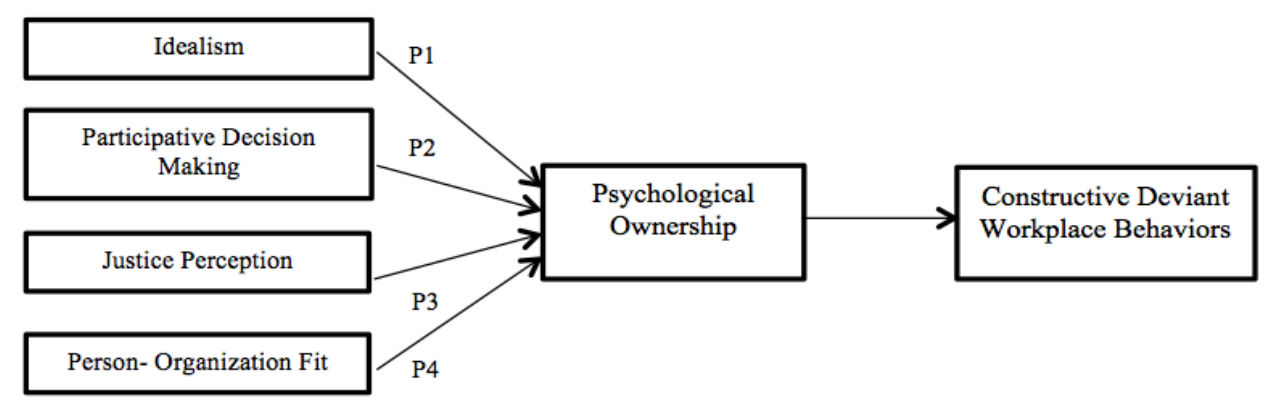

Figure 2. Proposed model

\section{Conclusion}

Because of today's organizations' focus on being more flexible, creative, innovative, decentralized and global, adding some extra values to contribute organization's well-being has become an obligation for its members to survive in their organizations. Of course, to do this, sometimes existing norms and procedures may not be sufficient. At this point, behaving deviantlly may be necessary to contribute organization's well-being and to maintain their existences in organizations. Although, the concept of deviance is widely used with negative meanings, as mentioned before, it is also used as a positive meaning in the literature. In this study, the concept of constructive (positive) deviance was investigated.

The present study began defining some constructs with related to the proposed model and reviewing the relevant literature of constructive deviant workplace behaviors. After explaining their rationales, we suggested several propositions related with six variables; constructive deviant workplace behaviors, participative decision-making, psychological ownership, person-organization fit, idealism and lastly justice perception. In this respect, several propositions were developed to test these predictive relationships (see Figure 2).

After the comprehensive literature review, we thought that this study shed light on these questions; (a) what might be some less studied antecedents of constructive deviant workplace behaviors, and (b) is psychological ownership a missing link between the antecedents and behaviors? According to these questions, based on the theoretical rationales it is easy to say that with regard to this study we tried to close the gap in constructive deviance literature. To do this, we discussed past researches, their contribution to the existing literature and shortcomings of it. Than, we determined some rarely studied predictors (i.e. justice perception, idealism, P-O fit and participative decision making, and psychological ownership). To present the relations among these variables 
we developed a conceptual model and propositions. An important contribution of this study, psychological ownership, as a positive attitude, was used as mediator in the proposed model (see Figure 2). Of course, in the past studies, psychological ownership has already been used as a mediator (see Table 1). However, in our proposed model, we proposed that some positive perceptions might cause constructive deviance trough psychological ownership. In other words, we propose that psychological ownership might be a missing link between predictors and constructive deviance.

Considering this relationship within the Blau's (1964) social exchange theory, we can say that if people perceive their organizations positively, they may feel obligated to behave positively to contribute its well-being (Vadera et al., 2013). From this aspect, we thought employee's feelings and propensities could lead to the constructive deviant behaviors trough the agency of psychological ownership. Besides, this theoretical study can be beneficial for practitioners and researchers. By means of this study, managers might develop some strategies to conduct some positive organizational changes and establish a favourable organizational milieu to support constructive deviance. For instance, managers should ensure fair and equitable environment to prevent negative perceptions and attitudes, which employees might have. In other words, they should establish a fair and trust focused organizational milieu to trigger positive attitudes. Top managers should encourage employees to participate in decision-making process and set ground for a suitable organizational structure to achieve this aim. HRM managers also should look for P-O fit as must in selecting or hiring activities to contribute to the organization's well-being. Informed about how ethical ideology has an effect on the morally questionable behaviors, managers may look for ethical ideology as an effective instrument, which used for predict and manage deviant behaviors. If these suggestions are realized and psychological ownership is maximized, positive attitudes such as; organizational trust and commitment may increase which then lead to constructive deviance.

Despite the aforementioned strengths, this study is not without limitations. Firstly, although there are two types of deviance (i.e. constructive and destructive) we only investigated constructive deviance. Therefore, destructive deviance lies outside the scope of this study. Further researches should investigate these two types of deviance at the same time to determine whether the dynamics underlying these two constructs are unique or not. Secondly, in this paper we tried to define some rarely used predictors that may be antecedents of constructive deviance. Further researches should try to define consequences of the constructive deviance such as; employee creative performance and innovative performance. Thirdly, it is obvious that in social sciences there are a great deal of attitudes or behaviors, which may affect constructive deviance, however, we only used five of them. Therefore, further research should explore the possibility that some other situational and contextual variables mediate or moderate these relations. In addition, further researcher may investigate the direct or moderator effect of personality variables.

So far, the theoretical limitations have been mentioned, however, there are also some demographic, instrumentation and research limitations. To illustrate, although the relationships among different constructs, in proposed model, have respectable theoretical rationales, it needs to apply on some suitable samples to its validity. For instance, this model can be used on employees working in informatics sector or other sectors, where innovativeness, flexibility and constructive deviance are required. Of course, although the construct definitions of the variables have explained in detail, there is still need to conduct robust quantitative analyses to test our propositions. Given the comprehensiveness of this study, any single study could test our propositions separately. Thereby, by means of these studies we could look at whether the theoretical linkages of our proposed model are supported or not. Another limitation concern, although the proposed model was not tested empirically in this study, it may be a guide for possible researches that according to past studies the measuring deviance by self-reported can be the best way (Bowling et al., 2011; Bowling \& Eschleman, 2010). Additionally, in this study we did not consider any emotional or situational factors, which can be control variables (i.e. emotional stability, negative affect, risk taking propensity) affecting our proposed linkages. Thus, further researches should take into account of these factors to better understand these relations. Lastly, although the present study is based on qualitative rationales, we believe that it will achieve its primary purpose when it is empirically tested by future researches.

\section{Acknowledgement}

An earlier version of this study was presented at $15^{\text {th }}$ Eurasian Business and Economics Society (EBES) Conference, 8-10 January 2015, Lisbon/Portugal.

\section{References}

Adams, J. S. (1963). Toward an understanding of inequity. Journal of Abnormal and Social Psychology, 67, 422-436. http://dx.doi.org/10.1037/h0040968 
Adams, J. S. (1965). Inequity in social exchange. In L. Berkowitz (Ed.), Advances in experimental social psychology (pp. 267-299). New York: Academic Press.

Aiken, M., \& Hage, J. (1966). Organizational alienation: A comparative analysis. American Sociological Review, 497-507.

Allen, B. H., \& LaFollette, W. R. (1977). Perceived organizational structure and alienation among management trainees. Academy of Management Journal, 20(2), 334-341.http://dx.doi.org/10.2307/255407

Alpkan, L., Ceylan, A., \& Aytekin, M. (2003). Performance impacts of operations strategies: A study on Turkish manufacturing firms. International Journal of Agile Manufacturing, 6(2).

Ambrose, M. L., Seabright, M. A., \& Schminke, M. (2002). Sabotage in the workplace: The role of organizational injustice. Organizational Behavior and Human Decision Processes, 89(1), 947-965. http://dx.doi.org/10.1016/S0749-5978(02)00037-7

Ang, S., Van Dyne, L., \& Begley, T. M. (2003). The employment relationships of foreign workers versus local employees: A field study of organizational justice, job satisfaction, performance, and OCB. Journal of Organizational Behavior, 24(5), 561-583. http://dx.doi.org/10.1002/job.202

Appelbaum, S. H., Iaconi, G. D., \& Matousek, A. (2007). Positive and negative deviant workplace behaviors: Causes, impacts, and solutions. Corporate Governance, 7(5), 586-598. http://dx.doi.org/10.1108/14720700710827176

Arslan, M., Alpkan, L., \& Elçi, M. (2003, September). The determinants of work ethic in Kocaeli. Present in 1st international business and professional ethics congress of Turkey, pp. 207-215. http://dx.doi.org/10.1016/j.sbspro.2011.09.135

Ateş, H., Yıldız, B., \& Yıldız, H. (2012). Herzberg'in çift faktör kurami kamu okullarinda çalişan öğretmenlerin motivasyon algilarini açiklayabilir mi? Ampirik bir araştirma. Bilgi Ekonomisi ve Yönetimi Dergisi, 7(2), $147-162$.

Avey, J. B., Avolio, B. J., Crossley, C. D., \& Luthans, F. (2009). Psychological ownership: Theoretical extensions, measurement and relation to work outcomes. Journal of Organizational Behavior, 30(2), 173-191. http://dx.doi.org/10.1002/job.583

Avey, J. B., Wernsing, T. S., \& Palanski, M. E. (2012). Exploring the process of ethical leadership: The mediating role of employee voice and psychological ownership. Journal of Business Ethics, 107(1), 21-34. http://dx.doi.org/10.1007/s10551-012-1298-2

Bennett, R. J., \& Robinson, S. L. (2000). Development of a measure of workplace deviance. Journal of Applied Psychology, 85(3), 349. http://dx.doi.org/10.1037/0021-9010.85.3.349

Bennett, R., \& Stamper, C. L. (2001). Corporate citizenship and deviancy: A study of discretionary work behavior. International Research in the Business Disciplines, 3, 265-284.

Black, J. S., \& Gregersen, H. B. (1997). Participative decision-making: An integration of multiple dimensions. Human Relations, 50(7), 859-878. http://dx.doi.org/10.1177/001872679705000705

Blau, P. M. (1964). Exchange and power in social life. Transaction Publishers.

Bodankin, M., \& Tziner, A. (2009). Constructive deviance, destructive deviance and personality: How do they interrelate. Amfiteatru Economic Journal, 11, 549-564.

Bowling, N. A., \& Eschleman, K. J. (2010). Employee personality as a moderator of the relationships between work stressors and counterproductive work behavior. Journal of Occupational Health Psychology, 15, 91-103. http://dx.doi.org/10.1037/a0017326.

Bowling, N. A., Burns, G. N., Stewart, S. M., \& Gruys, M. L. (2011). Conscientiousness and agreeableness as moderators of the relationship between neuroticism and counterproductive work behaviors: A constructive replication. International Journal of Selection and Assessment, 19, 320-330. http://dx.doi.org/10.1111/j.1468-2389.2011.00561.x

Bretz Jr, R. D., \& Judge, T. A. (1994). Person-organization fit and the theory of work adjustment: Implications for satisfaction, tenure, and career success. Journal of Vocational Behavior, 44(1), 32-54. http://dx.doi.org/10.1006/jvbe.1994.1003

Brief, A. P., \& Motowidlo, S. J. (1986). Prosocial organizational behaviors. Academy of Management Review, 11(4), 710-725. http://dx.doi.org/10.5465/AMR.1986.4283909 
Buchko, A. A. (1993). The effects of employee ownership on employee attitudes: An integrated causal model and path analysis. Journal of Management Studies, 30(4), 633-657. http://dx.doi.org/10.1111/j.1467-6486.1993.tb00319.x

Bulut, Ç., \& Alpkan, L. (2006). Behavioral consequences of an entrepreneurial climate within large organizations: An integrative proposed model. South East European Journal of Economics and Business, $1(2)$.

Byrne, Z. S., \& Cropanzano, R. (2001). History of organizational justice: The founders speak. In R. Cropanzano (Ed.), Advances in organizational justice: From theory to application (Vol. 2). Mahwah, NJ: Lawrence Erlbaum.

Cable, D. M., \& Judge, T. A. (1996). Person-organization fit, job choice decisions, and organizational entry. Organizational Behavior and Human Decision Processes, 67(3), 294-311. http://dx.doi.org/10.1006/obhd.1996.0081

Çakar, N. D., Ergün, E., Alpkan, L., \& Dalgın, M. (2004). Ethical climate's relationship to justice perceptions and citizenship behaviors: The comparison of two samples in Turkey. The Global Business and Technology Association.

Caplan, R. D. (1987). Person-environment fit theory and organizations: Commensurate dimensions, time perspectives and mechanisms. Journal of Vocational Behavior, 31(3), 248-267. http://dx.doi.org/10.1016/0001-8791(87)90042-X

Chi, N. W., \& Han, T. S. (2008). Exploring the linkages between formal ownership and psychological ownership for the organization: The mediating role of organizational justice. Journal of Occupational and Organizational Psychology, 81(4), 691-711. http://dx.doi.org/10.1348/096317907X262314

Chung, Y. W., \& Moon, H. K. (2011). The moderating effects of collectivistic orientation on psychological ownership and constructive deviant behavior. International Journal of Business and Management, 6(12), 65-77. http://dx.doi.org/10.5539/ijbm.v6n12p65

Crant, J. M. (2000). Proactive behavior in organizations. Journal of Management, 26, 435-462. http://dx.doi.org/10.1177/014920630002600304

Cropanzano, R., Prehar, C. A., \& Chen, P. Y. (2002). Using social exchange theory to distinguish procedural from interactional justice. Group \& Organization Management, 27(3), 324-351. http://dx.doi.org/10.1177/1059601102027003002

Elçi, M., \& Ve Alpkan, L. (2006). Etik iklimin örgütsel vatandaşlık davranışlarına etkileri. Hacettepe Üniversitesi, İktisadi ve İdari Bilimler dergisi, 24(1), 141-170.

Elçi, M., \& Alpkan, L. (2009). The impact of perceived organizational ethical climate on work satisfaction. Journal of Business Ethics, 84(3), 297-311. http://dx.doi.org/10.1007/s10551-008-9709-0

Elçi, M., Alpkan, L., \& Çekmecelioğlu, H. G. (2008, June). The influence of person-organization fit on the employee' perception of organizational performance. 4th International Strategic Management Conference (Bosnia-Hezogovina)(pp. 587-593). Sarajevo.

Elçi, M., Ergün, E., Yılmaz, C., \& Alpkan, L. (2004). Ethical climate and organizational performance: Evidence from a Turkish public organization. International Management Development Research Yearbook (pp. 235-242), 13th Annual World Business Congress of IMDA, Maastricht, the Netherlands.

Elçi, M., Şener, İ., Aksoy, S., \& Alpkan, L. (2012). The impact of ethical leadership and leadership effectiveness on employees' turnover intention: The mediating role of work related stress. Procedia-Social and Behavioral Sciences, 58, 289-297. http://dx.doi.org/10.1016/j.sbspro.2012.09.1003

Eren, E., Aren, S., \& Alpkan, L. (2000). İşletmelerde Stratejik Yönetim Faaliyetlerini Değerlendirme Araştırması. Doğuş Üniversitesi Dergisi, 1(1), 96-123.

Ergun, E., Bulut Ç., Alpkan, L., \& Demircan, N. (2004). Connecting the Link between corporate entrepreneurship and innovative perfromance (pp. 259-264). Global Business and Technology Association, Cape Town, South Africa.

Folger, R., \& Cropanzano, R. (1998). Organizational justice and human resource management. Thousand Oaks, CA: Sage.

Forsyth, D. R. (1980). A taxonomy of ethical ideologies. Journal of Personality and Social Psychology, 39(1), 
175. http://dx.doi.org/10.1037/0022-3514.39.1.175

Forsyth, D. R. (1992). Judging the morality of business practices: The influence of personal moral philosophies. Journal of Business Ethics, 11(5-6), 461-470. http://dx.doi.org/10.1007/BF00870557

Fox, S., Spector, P. E., \& Miles, D. (2001). Counterproductive work behavior (cwb) in response to job stressors and organizational justice: Some mediator and moderator tests for autonomy and emotions. Journal of Vocational Behavior, 59(3), 291-309. http://dx.doi.org/10.1006/jvbe.2001.1803

Galperin, B. L. (2012). Exploring the nomological network of workplace deviance: Developing and validating a measure of constructive deviance. Journal of Applied Social Psychology, 42(12), 2988-3025. http://dx.doi.org/ 10.1111/j.1559-1816.2012.00971.x

Galperin, B. L., \& Burke, R. J. (2006). Uncovering the relationship between workaholism and workplace destructive and constructive deviance: An exploratory study. The International Journal of Human Resource Management, 17(2), 331-347. http://dx.doi.org/10.1080/09585190500404853

Galperin, B. L. (2002). Determinants of deviance in the workplace: An empirical examination of Canada and Mexico. Unpublished doctoral dissertation, Concordia University, Montreal, Canada.

Gilbert, S., Laschinger, H. K. S., \& Leiter, M. (2010). The mediating effect of burnout on the relationship between structural empowerment and organizational citizenship behaviours. Journal of Nursing Management, 18(3), 339-348. http://dx.doi.org/10.1111/j.1365-2834.2010.01074.x

Greenberg, J. (1990). Employee theft as a reaction to underpayment inequity: The cost of pay cuts. Journal of Applied Psychology, 75(5), 561-568. http://dx.doi.org/10.1037/0021-9010.75.5.561

Greenberg, J. (1990b). Organizational justice: Yesterday, today, and tomorrow. Journal of Management, 16, 399-432. http://dx.doi.org/10.1177/014920639001600208

Greenberg, J. (2004). Stress fairness to fare no stress: Managing workplace stress by promoting organisational justice. Organisational Dynamics, 33(4), 352-365.

Greenberg, J., \& Scott, K. S. (1996). Why do workers bite the hands that feed them? Employee theft as a social exchange process. In B. M. Staw \& L. L. Cummings (Eds.), Research in Organizational Behavior (Vol. 18, pp. 111-55). Greenwich, CT: JAI Press.

Greenberg, J., \& Alge, B. J. (1998). Aggressive reactions to workplace injustice. In R. W. Griffin, A. O'Leary-Kelly, \& J. M. Collins (Eds.), Dysfunctional behavior in organizations, Part A: Violent and deviant behavior (pp. 83-117). London: JAI Press.

Hastings, S. E., \& Finegan, J. E. (2011). The role of ethical ideology in reactions to injustice. Journal of Business Ethics, 100(4), 689-703. http://dx.doi.org/10.1007/s10551-010-0704-x

Henle, C. A. (2005). Predicting workplace deviance from the interaction between organizational justice and personality. Journal of Managerial Issues, XVII(2), 247-263.

Henle, C. A., Giacalone, R. A., \& Jurkiewicz, C. L. (2005). The role of ethical ideology in workplace deviance. Journal of Business Ethics, 56(3), 219-230. http://dx.doi.org/10.1007/s10551-004-2779-8

Howell, J. M., \& Higgins, C. A. (1990). Champions of technological innovation. Administrative Science Quarterly, 35, 317-341.

Howell, J. M., Shea, C. M., \& Higgins, C. A. (2005). Champions of product innovations: Defining, developing, and validating a measure of champion behavior. Journal of Business Venturing, 20, 641-661. http://dx.doi.org/10.1016/j.jbusvent.2004.06.001

Jawad, M., Tabassum, T. M., Raja, S., \& Abraiz, A. (2013). Study on work place behaviour: Role of person-organization fit, person-job fit \& empowerment, evidence from Pakistan. Journal of Business and Management Sciences, 1(4), 47-54. http://dx.doi.org/10.12691/jbms-1-4-2

Jones, D. A., \& Skarlicki, D. P. (2005). The effects of overhearing peers discuss an authority's reputation for fairness on reactions to subsequent treatment. Journal of Applied Psychology, 90(2), 363-372. http://dx.doi.org/10.1037/0021-9010.90.2.363

Judge, T. A., \& Ferris, G. R. (1992). The elusive criterion of fit in human resource staffing decisions. Human Resource Planning, 15(4), 47-67.

Judge, T. A., \& Colquitt, J. A. (2004). Organizational justice and stress: The mediating role of work-family conflict. Journal of Applied Psychology, 89(3), 395. http://dx.doi.org/10.1037/0021-9010.89.3.395 
Khan, A. K., Quratulain, S., \& Crawshaw, J. R. (2013). The mediating role of discrete emotions in the relationship between injustice and counterproductive work behaviors: A study in Pakistan. Journal of Business and Psychology, 28(1), 49-61. http://dx.doi.org/10.1007/s10869-012-9269-2

Konovsky, M. A. (2000). Understanding procedural justice and its impact on business organizations. Journal of Management, 26, 489-511.http://dx.doi.org/10.1177/014920630002600306

Konovsky, M. A., \& Pugh, S. D. (1994). Citizenship behavior and social exchange. Academy of Management Journal, 37(3), 656-669. http://dx.doi.org/10.2307/256704

Krings, F., \& Facchin, S. (2009). Organizational justice and men's likelihood to sexually harass: The moderating role of sexism and personality. Journal of Applied Psychology, 94, 501-510. http://dx.doi.org/10.1037/a0013391

Kristof, A. L. (1996). Person - organization fit: An integrative review of its conceptualizations, measurement, and implications. Personnel Psychology, 49(1), 1-49. http://dx.doi.org/10.1111/j.1744-6570.1996.tb01790.x

Kristof-Brown, A. L., Zimmerman, R. D., \& Johnson, E. C. (2005). Consequences of individuals 'fit at work: A meta - analysis of person-job, person-organization, person-group, and person-supervisor fit. Personnel Psychology, 58(2), 281-342. http://dx.doi.org/10.1111/j.1744-6570.2005.00672.x

Leventhal, G. S., Karuza, J., \& Fry, W. R. (1980). Beyond fairness: A theory of allocation preferences. In G. Mikula (Ed.), Justice and social interaction (pp. 167-218). New york: Springer-Verlag.

Liu, B., Liu, J., \& Hu, J. (2010). Person-organization fit, job satisfaction, and turnover intention: An empirical study in the Chinese public sector. Social Behavior and Personality: An International Journal, 38(5), 615-625. http://dx.doi.org/10.2224/sbp.2010.38.5.615

Liu, J., Wang, H., Hui, C., \& Lee, C. (2012). Psychological ownership: How having control matters. Journal of Management Studies, 49(5), 869-895. http://dx.doi.org/10.1111/j.1467-6486.2011.01028.x

Mayhew, M. G., Ashkanasy, N. M., Bramble, T., \& Gardner, J. (2007). A study of the antecedents and consequences of psychological ownership in organizational settings. The Journal of Social Psychology, 147(5), 477-500. http://dx.doi.org/10.3200/SOCP.147.5.477-500

McFarlin, D. B., \& Sweeney, P. D. (1992). Research notes. Distributive and procedural justice as predictors of satisfaction with personal and organizational outcomes. Academy of Management Journal, 35(3), 626-637. http://dx.doi.org/10.2307/256489

McFerran, B., Aquino, K., \& Duffy, M. (2009). How personality and moral identity relate to individuals' ethical ideology. Business Ethics Quarterly, 20(1), 35-56. http://dx.doi.org/10.5840/beq20102014

McHoskey, J. W. (1996). Authoritarianism and ethical ideology. The Journal of Social Psychology, 136(6), 709-717. http://dx.doi.org/10.1080/00224545.1996.9712247

Moorman, R. H. (1991). Relationship between organizational justice and organizational citizenship behaviors: Do fairness perceptions influence employee citizenship? Journal of Applied Psychology, 76(6), 845. http://dx.doi.org/10.1037/0021-9010.76.6.845

Moorman, R. H., Niehoff, B. P., \& Organ, D. W. (1993). Treating employees fairly and organizational citizenship behavior: Sorting the effects of job satisfaction, organizational commitment, and procedural justice. Employee Responsibilities and Rights Journal, 6(3), 209-225. http://dx.doi.org/10.1007/BF01419445

Muchinsky, P. M., \& Monahan, C. J. (1987). What is person-environment congruence? Supplementary versus complementary models of fit. Journal of Vocational Behavior, 31(3), 268-277. http://dx.doi.org/10.1016/0001-8791(87)90043-1

Nassehi, A. (2005). Organizations as decision machines: Niklas Luhmann's theory of organized social systems. The Sociological Review, 53(1),178-191. http://dx.doi.org/10.1111/j.1467-954X.2005.00549.x

Netemeyer, R. G., Boles, J. S., MacKee, D. O., \& MacMurrian, R. (1997). An investigation into the antecedents of organizational citizenship behaviors in a personal selling context. Journal of Marketing, 61(3), 85-98.

Nye, J., \& Forsyth, D. R. (1984). The impact of ethical ideology on moral behavior. Eastern Psychological Association.

O’Driscoll, M. P., Pierce, J. L., \& Coghlan, A. M. (2006). The psychology of ownership work environment structure, organizational commitment, and citizenship behaviors. Group \& Organization Management, 31(3), 388-416. http://dx.doi.org/10.1177/1059601104273066 
O’Reilly, C. A., Chatman, J., \& Caldwell, D. F. (1991). People and organizational culture: A profile comparison approach to assessing personorganization fit. Academy of Management Journal, 34(3), 487-516. http://dx.doi.org/10.2307/256404

Örücü, E., \& Yıldız, H. (2014). İşyerinde kişisel internet ve teknoloji kullanımı: Sanal kaytarma. Ege Academic Review, 14(1). 99-114.

Özler, H., Yilmaz, A., \& Ozler, D. (2008). Psychological ownership: An empirical study on its antecedents and impacts upon organizational behaviors. Problems and Perspectives in Management, 6(3), 38-47.

Pierce, J. L., Kostova, T., \& Dirks, K. T. (2001). Toward a theory of psychological ownership in organizations. Academy of Management Review, 26(2), 298-310. http://dx.doi.org/10.5465/AMR.2001.4378028

Pierce, J. L., Kostova, T., \& Dirks, K. T. (2003). The state of psychological ownership: Integrating and extending a century of research. Review of General Psychology, 7(1), 84. http://dx.doi.org/10.1037/1089-2680.7.1.84

Pierce, J. L., O’driscoll, M. P., \& Coghlan, A. M. (2004). Work environment structure and psychological ownership: The mediating effects of control. The Journal of Social Psychology, 144(5), 507-534. http://dx.doi.org/10.3200/SOCP.144.5.507-534

Pierce, J. L., Rubenfeld, S. A., \& Morgan, S. (1991). Employee ownership: A conceptual model of process and effects. Academy of Management Review, 16(1), 121-144. http://dx.doi.org/10.5465/AMR.1991.4279000

Pierce, J. L., Van Dyne, L., \& Cummings, L. L. (1992). Psychological ownership: A conceptual and operational examination. Southern Management Association Proceedings, Valdosta, GA.

Podsakoff, P. M., MacKenzie, S. B., Moorman, R. H., \& Fetter, R. (1990). Transformational leader behaviors and their effects on followers' trust in leader, satisfaction and organizational citizenship behaviors. Leadership Quarterly, 1(2), 107-142. http://dx.doi.org/10.1016/1048-9843(90)90009-7

Porter, L. W., Lawler, E. E. III., \& Hackman, J. R. (1996). Ways groups influence individual work effectiveness. In R. M. Steers, L. W. Porter \& G. A. Bigley (Eds.), Motivation and leadership at work (pp. 346-354). New York: McGraw-Hill.

Robbins, D. L., \& Galperin, B. L. (2010). Constructive deviance: Striving toward organizational change in healthcare. Journal of Management and Marketing Research, 5, 1-11.

Robinson, S. L., \& Bennett, R. J. (1995). A typology of deviant workplace behaviors: A multidimensional scaling study. Academy of Management Journal, 38(2), 555-572. http://dx.doi.org/10.2307/256693

Ryan, R. M., \& Deci, E. L. (2000). Self-determination theory and the facilitation of intrinsic motivation, social development, and well-being. American Psychologist, $\quad 55(1), \quad 68$. http://dx.doi.org/10.1037/0003-066X.55.1.68

Schlenker, B. R., \& Forsyth, D. R. (1977). On the ethics of psychological research. Journal of Experimental Social Psychology, 13, 369-396. http://dx.doi.org/10.1016/0022-1031(77)90006-3

Sharkawi, S., Rahim, A. R. A., \& AzuraDahalan, N. (2013). Relationship between person-organization fit, psychological contract violation on counterproductive work behaviour. International Journal of Business and Social Science, 4(4), 173-183.

Sieger, P., Bernhard, F., \& Frey, U. (2011). Affective commitment and job satisfaction among non-family employees: Investigating the roles of justice perceptions and psychological ownership. Journal of Family Business Strategy, 2(2), 78-89. http://dx.doi.org/10.1016/j.jfbs.2011.03.003

Sieger, P., Zellweger, T., \& Aquino, K. (2013). Turning agents into psychological principals: Aligning interests of non - owners through psychological ownership. Journal of Management Studies, 50(3), 361-388. http://dx.doi.org/10.1111/joms.12017

Singhapakdi, A., Vitell, S. J., \& Franke, G. R. (1999). Antecedents, consequences, and mediating effects of perceived moral intensity and personal moral philosophies. Journal of the Academy of Marketing Science, 27(1), 19-36.

Skarlicki, D. P., \& Folger, R. (1997). Retaliation in the workplace: The roles of distributive, procedural, and interactional justice. Journal of Applied Psychology, 434. http://dx.doi.org/10.1037/0021-9010.82.3.434

Spreitzer, G. M., \& Sonenshein, S. (2003). Positive deviance and extraordinary organizing. In K. Cameron, J. Dutton \& R. Quinn (Eds.), Positive organizational scholarship (pp. 207-224). San Francisco: 
Berrett-Koehler.

Spreitzer, G. M., \& Sonenshein, S. (2004). Toward the construct definition of positive deviance. American Behavioral Scientist, 47(6), 828-847. http://dx.doi.org/10.1177/0002764203260212

Suárez-Mendoza, M. J., \& Zoghbi-Manrique-de-Lara, P. (2008). The impact of work alienation on organizational citizenship behavior in the Canary Islands. International Journal of Organizational Analysis, 15(1), 56-76. http://dx.doi.org/10.1108/19348830710860156

Syaebani, M. I., \& Sobri, R. R. (2013). Relationship between organizational justice perception and engagement in deviant workplace behavior. The South East Asian Journal of Management, 5(1), 37-50.

Treviño, L. K., \& Brown, M. E. (2005). The role of leaders in influencing unethical behavior in the workplace. In R. E. Kidwell \& C. L. Martin (Eds.), Managing organizational deviance (pp. 69-96). London: Sage Publishing.

Tziner, A., Fein, E. C., Sharoni, G., Bar-Hen, P., \& Nord, T. (2010). Constructive deviance, leader-member exchange, and confidence in appraisal: How do they interrelate, if at all? Desviación Constructiva, Intercambio Líder-Miembro y Confianza en la Evaluación: Cómo se Interrelacionan, si lo Hacen? Revista de Psicología del Trabajo y de las Organizaciones, 26(2), 95-100. http://dx.doi.org/10.4321/S1576-59622010000200001.

Vadera, A. K., Pratt, M. G., \& Mishra, P. (2013). Constructive deviance in organizations integrating and moving forward. Journal of Management, 1-56. http://dx.doi.org/10.1177/0149206313475816

Van Dyne, L., \& Pierce, J. L. (2004). Psychological ownership and feelings of possession: Three field studies predicting employee attitudes and organizational citizenship behavior. Journal of Organizational Behavior, 25(4), 439-459. http://dx.doi.org/10.1002/job.249

Van Dyne, L., Graham, J. W., \& Dienesch, R. M. (1994). Organizational citizenship behavior: Construct redefinition, measurement, and validation. Academy of Management Journal, 37(4), 765-802. http://dx.doi.org/10.2307/256600

Vandewalle, D., Van Dyne, L., \& Kostova, T. (1995). Psychological ownership: An empirical examination of its consequences. Group \& Organization Management, $210-226$. http://dx.doi.org/10.1177/1059601195202008

Wagner, S. H., Parker, C. P., \& Christiansen, N. D. (2003). Employees that think and act like owners: Effects of ownership beliefs and behaviors on organizational effectiveness. Personnel Psychology, 56(4), 847-871. http://dx.doi.org/10.1111/j.1744-6570.2003.tb00242.x

Warren, D. E. (2003). Constructive and destructive deviance in organizations. Academy of Management Review, 28(4), 622-632. http://dx.doi.org/10.5465/AMR.2003.10899440

Yıldız, B., \& Yıldız, H. (2014). İş yaşamındaki sanal kaytarma davranışlarının hukuki yönden incelenmesi. Yönetim ve Ekonomi Araştırmaları Dergisi, 13(2). (In press).

Y1ldiz, B., \& Alpkan, L. (2014, Nov). A theoretical model on the proposed predictors of destructive deviant workplace behaviors and the mediator role of alienation. In C. Zehir (Ed.), Leadership (pp. 501-509). Paper presented at the proceedings of the $4^{\text {th }}$ International Conference on Leadership, Technology and Innovation Management (Turkey), Y1ldız Technical University, Istanbul. http://dx.doi.org/10.13140/2.1.3218.9121

Yıldız, H., Yıldız, B., \& Ateş, H. (2014, Nov). Sanal kaytarma davranışlarının sergirilmesinde örgütsel adalet algisinın rolü var mıdır? $12^{\text {th }}$ International Conference on Knowledge, Economy and Management (Turkey) (pp. 169-180). Antalya. http://dx.doi.org/10.13140/2.1.3808.9289

\section{Copyrights}

Copyright for this article is retained by the author(s), with first publication rights granted to the journal.

This is an open-access article distributed under the terms and conditions of the Creative Commons Attribution license (http://creativecommons.org/licenses/by/3.0/). 